Egyptian Journal of Aquatic Biology \& Fisheries

Zoology Department, Faculty of Science,

Ain Shams University, Cairo, Egypt.

ISSN $1110-6131$

Vol. 23(2): 241 - 251 (2019)

www.ejabf.journals.ekb.eg

\title{
Performance assessment of Re-use Mariculture System for Mini Farm in Rearing Sparus aurata and Dicentrachus labrax
}

\author{
Amr M. Helal and Mona M. Mustafa \\ Fish Rearing Lab, Aquaculture Division, National Institute of Oceanography \& \\ Fisheries, Alexandria, Egypt. \\ amr_helal@yahoo.com; monamustafa153@yahoo.com
}

\section{ARTICLE INFO \\ Article History: \\ Received: Feb. 13, 2019 \\ Accepted: April 22, 2019 \\ Online: April 30, 2019}

Keywords:

Mariculture

Re-used water

Growth rate

Minifarm

Sparus aurata

Dicentrachus Labrax

\section{ABSTRACT}

The objective of the present research is to assess the performance of re-used mariculture system on growth rate and percent survival of $S$. aurata and D. labrax fish; more over to evaluate water quality, which affects fish production. The results revealed that the degree of re-used sea water was $96.7 \%$ which equal $65 \mathrm{~L}$ daily and the new water added $/ \mathrm{Kg}$ fish was $8.8 \mathrm{~L} / \mathrm{Kg}$ juvenile $S$. aurata daily and $3.28 \mathrm{~L} / \mathrm{Kg}$ fries D. labrax daily. The physicochemical and biological water measurement $\left(\mathrm{T}^{\circ} \mathrm{c}, \mathrm{pH}, \mathrm{S} \%\right.$, DO, $\mathrm{NH}_{3}, \mathrm{NH}_{4}{ }^{+}, \mathrm{NO}_{2}^{-}, \mathrm{NO}_{3}{ }^{-}$and $\mathrm{BOD}$ ) are in acceptable range in the two experiments for $S$. aurata and D. labrax. The result explained that the survival rate were $96 \%$ and $91 \%$ for $S$. aurata and $76.7 \%$ and $81.6 \%$ for $D$. Labrax in Tank1 and Tank2 respectively. The growth performance parameters (WG, ADG, SGR, FCR, PER and K) were reported for the two experiments. The length-weight relationship for $S$. aurata indicate that the high length, the increase in weight with $\mathrm{R}^{2}=0.9596$ and 0.9966 for Tank1 and Tank 2 comparing with 0.8474 for control. Therefore the significant success of rearing $S$. aurata and D. labrax in RMS for mini farm was achieved in water management by improving the efficiency of biological filter.

\section{INTRODUCTION}

In recent years, animal protein becomes a main problem in several countries like Egypt; therefore we must reduce the gap between production and animal protein consumption special fish protein. In Egypt, aquaculture is become an increasingly important activity as source of fish protein required for the increase population (Savary-Auzeloux et al, 2014).

Mariculture is a growth industry demarche to satisfy a growing market for food fish. It currently is the overgrowth sectors of aquaculture in Egypt. Farms of rearing S. Aurata (sea bream) and D. Labrax (sea bass) are help to increase profitability in the last years (FAO, 2013).

Re-use Mariculture system (RMS) is essentially a technology for farming marine fish species by reusing the marine water in the production. It is depend on the use of bio-filters. RMS can be used out at different intensities depending on how much water is re-used.

Re-use marine water enables the fish farm manager to control and easy management for the parameters of production, and the skills of the manager to 
operate the reused system itself becomes just as important as his capacity to take care of the fish (FAO, 2015).

The modern mariculture has been practiced on intensive form base on the management of fish production and water quality. A sustainable mariculture industry acquires high seed quality with raising the survival percentage and growth performance (FAO, 2013).

Water quality is the primary important factor affects the larvae and juvenile stages production reared in ponds or tanks. Also, it deem the most tricky production factor to understands and predict to management. Water is not just where fish live but its quality affects on the feed efficiency, growth rate, fish health and survival percentage (Sipaúba-Tavares and Magalhães Santeiro, 2013).

The water quality utilized for aquaculture is one of the important factors affecting fish production to maximum performance. Water quality of fish farm must be appropriate in terms of temperature, salinity, color, neither acidic nor alkaline, contain enough DO and not be muddy or turbid (Iliyasu et al, 2016)

Therefore, this research aimed to manage and assessment the RMS in rearing D. labrax larvae and juvenile stage of S. aurata, also determine the growth rate and percent survival for these species during its experimental rearing.

\section{MATERIALS AND METHODS}

\section{Re-use Mariculture System:}

Re-use Mariculture System (RMS) for mini fish farm is a closed system located at National Institute of Oceanography \& Fisheries - El-Anfoshy, Alexandria. RMS is a naval and modern way for rearing fish in mini farms Instead of the traditional method of growing fish. It's a system to optimize production through a limited supply of water, with complete control for environmental to optimize fish growth. RMS is a technology for recycling of treated water as a closed system in the fish farms production. It is depend on utilize of filters biological and RMS can be utilized for any species of aquaculture.

RMS consist of two rearing tanks (T1\&T2) the capacity of each one is 2000L, one Sedimentation tank ST has two levels 0.25 and $0.5 \mathrm{~m}$, Bio-Filter BF (consist of three layers gravel sea shell, pottery and coal) and Pump (P) to remain water volume constant (Fig.1). The degree of reused water was calculated as following:

\section{$\mathbf{R}=\left(\mathbf{1}-\mathbf{Q}_{\mathrm{B}} / \mathbf{Q}_{\mathrm{T}}\right) \times \mathbf{1 0 0}$}

$\mathrm{R}$ : Degree of reused water.

$\mathrm{Q}_{\mathrm{B}}$ : The amount of water in the exchange batch/day.

$\mathrm{Q}_{\mathrm{T}}$ : Total water volume in tank.

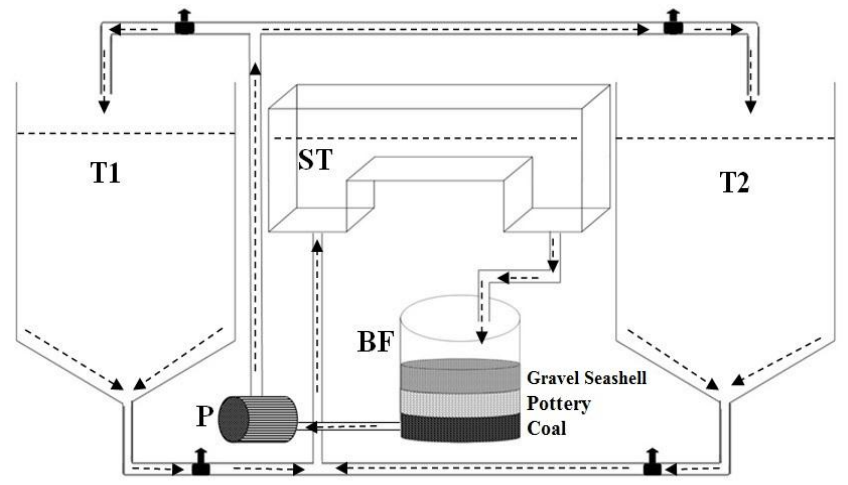

Fig. 1: Re-use Mariculture System Design

* T1\&T2: Rearing Tanks; ST: Sedimentation tank; BF: Bio-Filter; P: Pump 
The degree of re-use water does not give sufficient information about the performance of the RMS and is not enough to describe a re-used system properly. There for it must be take in regard the quantity of fish in the system to describe RMS it will also be necessary to know the amount of new water added/Kg fish (Liters new water/Kg fish) using the following equation:

New Water Add L/min

Total amount of fish/Kg

\section{Parameters measurement:}

Water sampling was conducted weekly from T1 and T2.

\section{Physiochemical and Biological Parameters \\ Temperature} minutes.

Water temperature was measure by dipping the bucket thermometer for a few pH

$\mathrm{pH}$ values were measure immediately using a Lovibond Water Testing, SensoDirect 150.

\section{Salinity}

Salinity values were measure immediately using a Digital Refractometers for Sea Water Measurements.

\section{Dissolved Oxygen}

DO was analyzed according to Azide method that was approved by AOAC methods (AOAC, 1995).

\section{Ammonium}

Ammonia and nitrogenous oxide were analyzed by using ammonia nitrogen test kit "La Motte" solving analytical challenges.

\section{Biological Oxygen Demand}

BOD was analyzed according to standard Association of official analytical chemistry AOAC methods (AOAC, 1995).

\section{RMS Management:}

The water quality used for fish culture is one of the important factors affecting fish yield for optimum performance fish species being culture. Good water quality, must be neutral $\mathrm{pH}$ value contain enough dissolved oxygen, clear, with suitable temperature and salinity.

To face mariculture problems, water quality parameters should be monitored to serve as guide for managing RMS, thus conditions that can adversely affect the growth of fish can be avoided.

Two experiments were designed to assessment the RMS:

\section{First Experiment:}

The first experiment was conducted on Sea Bream (Sparus aurata). The source of stocking fingerlings Sea Bream was collected from Domietta region and nursed in the tanks for 10 days. The fingerlings of Sea Bream with mean weight $36.0 \pm 0.66 \mathrm{gm}$ by average length $14.0 \pm 0.22 \mathrm{~cm}$ were reared in the same two rearing tank at rate 100 fingerlings $/ 1000 \mathrm{~L}$, during the period from November to May.

\section{Second Experiment:}

The second experiment was conducted on Sea Bass (Dicentrachus labrax). The source of stocking fingerlings Sea Bass was collected from Domiatta region and nursed in the tanks for 10 days. The fingerlings of Sea Bass with mean weight $2.5 \mathrm{gm}$ by average length $8.5 \mathrm{~cm}$ were reared in the two rearing tank at rate 100 fingerlings /1000L, during the period from March to June. 
The feeding rate was $4 \%$ of fish total weight twice time daily. The commercial supplementary feed meal was from Aller Aqua. The dietary ingredients and proximate composition used in RMS (Table 1).

Table 1: Dietary Ingredients and Proximate Composition of S. aurata and D. Labrax Reared in RMS System Mini Fish Farm

\begin{tabular}{ll}
\hline Ingredients $\left(\mathbf{g ~ k g}^{-1}\right)$ (Protein \%) & Dietary Treatments \% \\
\hline Fish Herring meal (76\%) & 24 \\
Fish meal $(65 \%)$ & 10 \\
Soybean meal $(48 \%)$ & 14 \\
Soybean meal $(44 \%)$ & 6 \\
Wheat Gluten $(80 \%)$ & 7 \\
Wheat flour & 10 \\
Corn Gluten $(60 \%)$ & 11 \\
Fish oil & 11.50 \\
Brewers yeast & 2 \\
Mono Calcium Phosphate & 2 \\
Krill meal(62\%) & 1.5 \\
Min. premix1 & 0.5 \\
Vitamins2 & 0.5 \\
Energy & $4644 \mathrm{kcal} / \mathrm{kg}$ \\
Total & 100 \\
Proximate composition $(\%)$ & \\
Crude Protein & $48.5 \pm 2.1$ \\
Crude fat & $14.6 \pm 0.6$ \\
Crude Fiber & $2.7 \pm 0.1$ \\
Ash & $8.3 \pm 0.2$ \\
Moisture & $10.1 \pm 0.5$ \\
NFE3 & $25.9 \pm 3.2$ \\
\hline
\end{tabular}

1: Vitamins premix (mg kg $\left.{ }^{-1}\right)$; p-amino benzoic acid (9.48); D-Biotin (0.38); Inositol (379.20); Niacin (37.92); Ca-pantothenate (56.88); Pyridoxine-HCl (11.38); Riboflavin (7.58); Thiamine-HCl (3.79); L-ascorbyl-2-phosphate Mg (APM) (296.00); Folic acid (0.76); Cyanocobalamine (0.08); Menadione (3.80), Vitamin A-palmitate (17.85); $\alpha$-tocopherol (18.96); Calciferol (1.14).

2: Minerals premix ( $\mathrm{mg} \mathrm{kg}^{-1}$ ) Copper (70);Zinc(70) ;Manganese(12) ; Iodine(3) ;Selenium(2)

3: Nitrogen-free extracts $(\mathrm{NFE})=1000-[$ Ash + lipid + protein + Fiber $]\left(\mathrm{g} \mathrm{kg}^{-1}\right)$.

\section{Growth Measurements:}

The fish in each experimental tank were weighed to nearest gm and measured individually to nearest $\mathrm{mm}$ at beginning and end of the experiment to calculate the growth rate, survival percentage, gain weight and specific growth rate in each experiment as the following:

$$
\begin{aligned}
& \text { Percent gain weight }=\frac{\text { Final weight }- \text { Initial weight }}{\text { Initial weight }} \times 100 \\
& \text { SGR }=\frac{\text { Ln final weight }- \text { Ln initial weight }}{\text { Period/day }}
\end{aligned}
$$

Length-Weight Relationship:

The length-weight relationship for fish can be identifying by using the equation (Le Cren, 1951):

Where:

$$
\mathrm{W}=\mathrm{aL}^{\mathrm{b}}
$$

$\mathrm{W}=$ Weight of fish $(\mathrm{g})$.

$\mathrm{L}=$ Total length of fish $(\mathrm{cm})$.

$\mathrm{a}=\mathrm{Y}-$ Intercept or the Initial growth index.

$\mathrm{b}=$ Slope or the growth coefficient or an exponent. 


\section{RESULTS AND DISCUSSION}

\section{Assessment of RMS Management:}

The re-used water can be expressed either as percentage or amount of water exchanged. The percentage of water exchanged in relation to the total flow in the system through day and night or it can give as the amount of exchanged water in relation to the total volume of water to remain the water volume in tanks constant.

The result exposed that the degree of re-used water in the RMS equal $96.7 \%$ and the rate of water exchange due to siphoning to eliminate the organic waste from bottom of the tanks and due to evaporation factors equal 3.3\% of the total water volume of each tank which equal $65 \mathrm{~L} /$ daily.

Moreover, to evaluate the RMS it will be also necessary to know the amount of new water added per $\mathrm{Kg}$ fish $(\mathrm{L} / \mathrm{Kg}$ fish), the results revealed that the new water added/Kg fish in initial and final experiment equal $8.8 \mathrm{~L} / \mathrm{Kg}$ daily and $3.28 \mathrm{~L} / \mathrm{Kg}$ for sea bass and sea bream respectively.

\section{Physiochemical and Biological Parameters Temperature:}

The degree of water temperature for the first experiment are revealed that the monthly mean water temperature reached its lowest value in winter $13^{\circ} \mathrm{c}$ and $14^{\circ} \mathrm{c}$ during January and February and then it rose during April to $22^{\circ} \mathrm{C}$ as shown in Table 2 . While, the results for the second experiment are revealed that the mean monthly temperature ranged between $21^{\circ} \mathrm{C}$ and $23^{\circ} \mathrm{c}$ during summer season (Table 4).

The suitable water temperature range for grows $O$. niloticus, $M$. Capito and $D$. Labrax ranged between $15-35{ }^{\circ} \mathrm{C}$ (Attia et al., 2017), these results are agreement with the present results.

pH:

Measurement of $\mathrm{pH}$ in aquatic habitat is essential as it reflects the biological activity and changes in the water as well as pollution. The mean monthly $\mathrm{pH}$ value in the first experimental period for sea bream range between $8.55 \pm 0.02$ and $8.68 \pm$ 0.01 in $\mathrm{T} 1$ while in $\mathrm{T} 2$, the $\mathrm{pH}$ value range between $7.53 \pm 0.01$ and $8.55 \pm 0.02$ as minimum and maximum values respectively (Table 2 ).

Moreover, in the second experimental period for sea bass the mean monthly $\mathrm{pH}$ value ranged between 7.53 and 7.66 as minimum value while 8.55 and 8.76 as maximum value in $\mathrm{T} 1$ and $\mathrm{T} 2$ respectively (Table 4 ).

The suitable $\mathrm{pH}$ range for fish culture is between 6.7 and 9.5 and the ideal $\mathrm{pH}$ value is between 7.5 and 8.5 , while $\mathrm{pH}$ value above or below is stressful to the fishes. Therefore the present results seem to be much suitable for fish culture and in agreement with the findings (Attia et al., 2017).

\section{Salinity:}

Salinity plays an important role in the growth of culture organism through osmoregulations of body minerals from the surrounding water. Moreover, it is the most significant factors which affect the survival of fish (Jamabo, 2008; Iliyasu et al., 2016). Generally, the result revealed that the mean water salinity ranged between 35 and 37 ppt (Tables 2 and 4) in the first and second experiments respectively.

\section{Dissolved Oxygen:}

DO is the most limiting factor in aquaculture. There for, it is considered as the most important and useful parameter for assessing the degree of water quality. It affects the growth, survival, distribution, behavior and physiology of aquatic organism (Ekubo and Abowei, 2011). 
The present results revealed that the mean monthly DO value in first experimental period for $S$. aurata ranged between $5.07 \pm 0.07 \mathrm{mg} / 1$ and $5.03 \pm$ $0.03 \mathrm{mg} / \mathrm{l}$ as minimum value and $5.607 \pm 0.01 \mathrm{mg} / \mathrm{l}$ and $5.83 \pm 0.01 \mathrm{mg} / \mathrm{l}$ as maximum value in $\mathrm{T} 1$ and $\mathrm{T} 2$ respectively (Table 2 ). While, the results in the second experiment for D. Labrax the mean monthly DO value ranged between $3.26 \mathrm{mg} / \mathrm{l}$ and $3.78 \mathrm{mg} / \mathrm{l}$ as minimum value and $8.98 \mathrm{mg} / \mathrm{l}$ and $5.1 \mathrm{mg} / \mathrm{l}$ as maximum value in $\mathrm{T} 1$ and $\mathrm{T} 2$ respectively (Table 4 ).

These result considered in adequate value in aquaculture and agreement with (Ekubo and Abowei, 2011) which recommended that the lowest concentration of 1.0 $\mathrm{mg} / \mathrm{l} \mathrm{DO}$ is essential to sustain fish for long period and $5.0 \mathrm{mg} / \mathrm{l}$ are adequate in fish farm. The environmental management of pond fish farms explains that for good water quality; maintain the DO level at above $4 \mathrm{mg} / \mathrm{l}$. The present study is revealed agreement with (Saloom and Duncan, 2005).

Table 2: Monthly Water Quality for (T1\& T2) of S. Aurata Reared in RMS System Mini Fish Farm

\begin{tabular}{|c|c|c|c|c|c|c|c|}
\hline & \multirow[t]{2}{*}{$\operatorname{Temp}^{\circ}$} & \multicolumn{2}{|c|}{$\begin{array}{c}\mathbf{p H} \\
\text { Mean } \pm \mathrm{SE}\end{array}$} & \multicolumn{2}{|c|}{ S. ppt. } & \multicolumn{2}{|c|}{$\begin{array}{c}\text { DO }(\mathrm{mg} / \mathrm{l}) \\
\text { Mean } \pm \mathrm{SE}\end{array}$} \\
\hline & & T1 & T2 & T1 & T2 & T1 & T2 \\
\hline November & 17 & $8.68 \pm 0.01$ & $8.53 \pm 0.03$ & 36 & 36 & $5.67 \pm 0.04$ & $5.10 \pm 0.03$ \\
\hline December & 19 & $8.64 \pm 0.02$ & $8.42 \pm 0.03$ & 37 & 37 & $5.50 \pm 0.05$ & $5.08 \pm 0.05$ \\
\hline January & 13 & $8.57 \pm 0.01$ & $7.53 \pm 0.01$ & 35 & 35 & $5.45 \pm 0.08$ & $5.03 \pm 0.09$ \\
\hline February & 14 & $8.56 \pm 0.02$ & $8.55 \pm 0.02$ & 36 & 36 & $5.43 \pm 0.01$ & $5.07 \pm 0.07$ \\
\hline March & 19 & $8.55 \pm 0.02$ & $8.54 \pm 0.02$ & 36 & 36 & $5.07 \pm 0.07$ & $5.03 \pm 0.03$ \\
\hline April & 22 & $8.68 \pm 0.01$ & $8.54 \pm 0.02$ & 37 & 37 & $5.67 \pm 0.04$ & $5.83 \pm 0.04$ \\
\hline Average & 17 & 8.61 & 8.31 & 36.7 & 36.7 & 5.46 & 5.2 \\
\hline
\end{tabular}

Table 4: Monthly Water Quality for (T1 \& T2) of D. Labrax Reared in RMS System Mini Fish Farm

\begin{tabular}{lccccccc}
\hline & \multirow{2}{*}{ Temp $^{\circ}$} & \multicolumn{2}{c}{ pH mean } & \multicolumn{2}{c}{ S. ppt. mean } & \multicolumn{2}{c}{ DO $(\mathbf{m g} / \mathbf{l})$ mean } \\
\cline { 3 - 8 } & & T1 & T2 & T1 & T2 & T1 & T2 \\
\hline May & 21 & 8.23 & 8.23 & 36 & 36 & 5.9 & 5.1 \\
June & 23 & 8.42 & 8.33 & 37 & 37 & 4.02 & 4.02 \\
July & 21 & 7.53 & 7.66 & 35 & 35 & 8.98 & 4.98 \\
August & 23 & 8.55 & 8.76 & 36 & 36 & 3.26 & 3.78 \\
Average & 22 & 8.18 & 8.25 & 36 & 36 & 4.79 & 4.47 \\
\hline
\end{tabular}

\section{Total Ammonia Nitrogen}

Total Ammonia Nitrogen (TAN) is the by product from protein metabolism excreted by fish and bacterial decomposition of organic matter as wasted feed, feces and dead plankton (Fahmy, 2001).

In the first experimental period result detect that the mean unionize ammonia $\left(\mathrm{NH}_{3}\right)$ in $\mathrm{T} 1$ and $\mathrm{T} 2$ fluctuated throughout from $0.041 \mathrm{mg} / \mathrm{l}$ and $0.01 \mathrm{mg} / \mathrm{l}$ as lowest value at the beginning of rearing period. It increases gradually to attain its highest value $1.043 \mathrm{mg} / \mathrm{l}$ and $0.14 \mathrm{mg} / \mathrm{l}$ at the end of experimental period respectively for $s$. aurata (Table 3).

While, in second experiment the mean $\mathrm{NH}_{3}$ value in $\mathrm{T} 1$ and $\mathrm{T} 2$ are recorded $0.04 \mathrm{mg} / \mathrm{l}$ and $0.07 \mathrm{mg} / \mathrm{l}$ as minimum value and $0.1 \mathrm{mg} / \mathrm{l}$ and $0.18 \mathrm{mg} / \mathrm{l}$ as maximum value respectively for D. labrax (Table 5).

Whereas, the result revealed that the monthly mean ionized ammonia $\left(\mathrm{NH}_{4}{ }^{+}\right)$in $\mathrm{T} 1$ and $\mathrm{T} 2$ are increased progressively from $0.16 \mathrm{mg} / \mathrm{l}$ and $0.08 \mathrm{mg} / \mathrm{l}$ as minimum value at the beginning of rearing period to attain maximum value $0.76 \mathrm{mg} / \mathrm{l}$ and 0.74 $\mathrm{mg} / \mathrm{l}$ at the end of experiment period respectively for $s$. aurata (Table 3).

While the results exposed that the mean ionized ammonia $\mathrm{NH}_{4}{ }^{+}$in $\mathrm{T} 1$ and $\mathrm{T} 2$, increased progressively from $0.16 \mathrm{mg} / \mathrm{l}$ and $0.08 \mathrm{mg} / \mathrm{l}$ as minimum value at the 
beginning of rearing period to attain maximum value $0.76 \mathrm{mg} / \mathrm{l}$ and $0.74 \mathrm{mg} / \mathrm{l}$ at the end of experimental period respectively (Table 3 ).

But, in the second experiment for D. labrax the mean $\mathrm{NH}_{4}{ }^{+}$value in $\mathrm{T} 1$ and $\mathrm{T} 2$ ranged between $0.99 \mathrm{mg} / \mathrm{l}$ and $1.10 \mathrm{mg} / \mathrm{l}$ as highest value to $0.7 \mathrm{mg} / \mathrm{l}$ and $0.7 \mathrm{mg} / \mathrm{l}$ as lowest value respectively (Table 5).

Ahmed et al., (2015) explained that the ammonia level ranged between 0.5 to 2 $\mathrm{mg} / \mathrm{l}$, caused high mortality for fish and the desirable limit of ammonia is $0-0.05$ $\mathrm{mg} / \mathrm{l}$ and acceptable limit less than 0.5mg/l. Also, (Bhatangar and Devi, 2013) recorded that the level of ammonia less than $0.2 \mathrm{mg} / \mathrm{l}$ to be suitable for fish culture the present results are agree with acceptable limit.

\section{Nitrite:}

Nitrite is the most unstable compound of inorganic forms because of its intermediate position in oxidation reduction process between ammonia and nitrate, that is mean nitrite appear in water mainly as a result of biochemical oxidation ammonia (nitrification).

The monthly mean recorded results of $\mathrm{NO}_{2}{ }^{-}$explained that it fluctuate from $0.176 \mathrm{mg} / \mathrm{l}$ and $0.12 \mathrm{mg} / \mathrm{l}$ as minimum value to $0.332 \mathrm{mg} / \mathrm{l}$ and $0.23 \mathrm{mg} / \mathrm{l}$ as maximum value in $\mathrm{T} 1$ and $\mathrm{T} 2$ respectively in the first experiment (Table 3 ).

Therefore, the present results illustrated that the average Nitrite values were in T1 higher than that in T2 for $S$. aurata. While, the result of D. labrax in the second experiment detected that the monthly mean value of $\mathrm{NO}_{2}{ }^{-}$ranged between $2.79 \mathrm{mg} / \mathrm{l}$ and $2.00 \mathrm{mg} / \mathrm{l}$ as highest value and $1.3 \mathrm{mg} / \mathrm{l}$ and $1.43 \mathrm{mg} / \mathrm{l}$ as a lowest value in $\mathrm{T} 1$ and $\mathrm{T} 2$ respectively (Table 5 ).

The nitrite desirable limit is zero as a normal and ideal measurement in any aquatic system. Stone and Thomforde (2004) recommended that the nitrite acceptable range less than $4 \mathrm{mg} / \mathrm{l}$ and according to (Santhosh and Singh, 2007) recorded nitrite concentration in water should never exceed $0.5 \mathrm{mg} / \mathrm{l}$.

While, (OATA, 2008) recommended that the nitrite should not override 0.2 $\mathrm{mg} / \mathrm{l}$ in freshwater and $0.125 \mathrm{mg} / \mathrm{l}$ in seawater. While (Bhatnagar and Devi, 2013) reported that the acceptable range of nitrite ranged between $0.02-2.00 \mathrm{mg} / \mathrm{l}$, therefore the present results are in acceptable range.

Nitrate:

Nitrate is the end of nitrification product process in natural water; it is mean that nitrate is the most stable form of inorganic nitrogen in oxygenated water.

The present results in the first experiment detected that the monthly mean water nitrate $\left(\mathrm{NO}_{3}{ }^{-}\right)$in $\mathrm{T} 1$ and $\mathrm{T} 2$ fluctuated from $0.91 \mathrm{mg} / \mathrm{l}$ and $0.83 \mathrm{mg} / \mathrm{l}$ as highest value to $0.62 \mathrm{mg} / \mathrm{l}$ and $0.54 \mathrm{mg} / \mathrm{l}$ as lowest value respectively for $S$. aurata (Table 3).

In the second experiment the results recorded that the monthly mean value of $\mathrm{NO}_{3}{ }^{-}$ranged between $2.71 \mathrm{mg} / \mathrm{l}$ and $2.31 \mathrm{mg} / \mathrm{l}$ as minimum value and $4.12 \mathrm{mg} / \mathrm{l}$ and $3.78 \mathrm{mg} / \mathrm{l}$ as maximum value in $\mathrm{T} 1$ and $\mathrm{T} 2$ respectively for $D$. labrax (Table 5).

Stone and Thomforde (2004) recorded that the nitrate is comparatively non toxic to fish and not cause any health hazard except at exceedingly high levels (above $90 \mathrm{mg} / \mathrm{l}$ ), as well as (Santhosh and Singh, 2007) reported the suitable range of $0.1 \mathrm{mg} / \mathrm{l}$ to $4.0 \mathrm{mg} / \mathrm{l}$ in fish farm water. However, (OATA, 2008) recommends that nitrate levels in marine water not exceed $100 \mathrm{mg} / \mathrm{l}$. It can be concluded that nitrate range in the acceptable limit.

\section{Biological Oxygen Demand:}

Biological Oxygen Demand (BOD) is measurement of total DO consumed by micro organism for biodegradation of organic matter such as food particles or sewage. 
The mean monthly BOD value fluctuated from $6.20 \mathrm{mg} / \mathrm{l}$ and $6.53 \mathrm{mg} / \mathrm{l}$ as maximum values to $5.35 \mathrm{mg} / \mathrm{l}$ and $5.27 \mathrm{mg} / \mathrm{l}$ as minimum value in $\mathrm{T} 1$ and $\mathrm{T} 2$ respectively for $S$. aurata (Table 3 ). Whilst, in the second experiment for D. labrax the BOD value ranged between $4.29 \mathrm{mg} / \mathrm{l}$ and $4.18 \mathrm{mg} / \mathrm{l}$ as lowest value to $5.23 \mathrm{mg} / \mathrm{l}$ and $4.55 \mathrm{mg} / \mathrm{l}$ as highest value in $\mathrm{T} 1$ and $\mathrm{T} 2$ respectively (Table 5).

BOD is the measurement of DO consumed by microorganisms for biodegradation of organic matter such as food particles or sewage. The BOD level between 3.0-6.0 mg/l is optimum for normal activities of fishes; $6.0-12.0 \mathrm{mg} / \mathrm{l}$ is sublethal to fishes and greater than $12.0 \mathrm{mg} / \mathrm{l}$ can usually cause death of fish due to suffocation (Bhatnagar et al., 2004). The optimal BOD level for fish farm should be less than $10 \mathrm{mg} / \mathrm{l}$, however the water with BOD less than $10 \mathrm{mg} / \mathrm{l}$ can be considered suitable for fish culture (Attia et al., 2017). There for the present result revealed that BOD value are in acceptable range.

Table 3: Monthly Water Quality for (T 1\& T2) of Sea-Bream Reared in RMS System Mini Fish Farm

\begin{tabular}{|c|c|c|c|c|c|c|c|c|c|c|}
\hline & \multicolumn{2}{|c|}{$\begin{array}{c}\mathrm{NH}_{3}(\mathrm{mg} / \mathrm{l}) \\
\text { Mean }\end{array}$} & \multicolumn{2}{|c|}{$\begin{array}{c}\mathrm{NH}_{4}^{+}(\mathrm{mg} / \mathrm{l}) \\
\text { Mean }\end{array}$} & \multicolumn{2}{|c|}{$\begin{array}{c}\mathrm{NO}_{2}^{-}(\mathrm{mg} / \mathrm{l}) \\
\text { Mean }\end{array}$} & \multicolumn{2}{|c|}{$\begin{array}{c}\mathrm{NO}_{3}^{-}(\mathrm{mg} / \mathrm{l}) \\
\text { Mean }\end{array}$} & \multicolumn{2}{|c|}{$\begin{array}{c}\text { BOD }(\mathrm{mg} / \mathrm{l}) \\
\text { Mean }\end{array}$} \\
\hline & T1 & T2 & T1 & T2 & T1 & $\mathbf{T} 2$ & T1 & $\mathbf{T 2}$ & T1 & T2 \\
\hline Nove. & 0.041 & 0.01 & 0.16 & 0.08 & 0.332 & 0.23 & 0.91 & 0.83 & 6.20 & 5.53 \\
\hline Dec. & 1.043 & 0.01 & 0.19 & 0.08 & 0.234 & 0.17 & 0.87 & 0.74 & 6.03 & 5.43 \\
\hline Jan. & 0.047 & 0.02 & 0.22 & 0.09 & 0.199 & 0.16 & 0.75 & 0.68 & 5.46 & 6.53 \\
\hline Feb. & 0.055 & 0.11 & 0.27 & 0.59 & 0.167 & 0.17 & 0.68 & 0.62 & 5.41 & 5.35 \\
\hline March & 0.112 & 0.12 & 0.59 & 0.66 & 0.176 & 0.14 & 0.62 & 0.58 & 5.35 & 5.32 \\
\hline April & 0.041 & 0.14 & 0.76 & 0.74 & 0.332 & 0.12 & 0.91 & 0.54 & 6.20 & 5.27 \\
\hline Average & 0.22 & 0.08 & 0.36 & 0.43 & 0.24 & 0.15 & 0.79 & 0.63 & 5.77 & 5.58 \\
\hline
\end{tabular}

Table 5: Monthly Water Quality for (T1 \&T2) of D. Labrax Reared in RMS System Mini Fish Farm

\begin{tabular}{lcccccccccc}
\hline & $\begin{array}{c}\mathbf{N H}_{3}(\mathbf{m g} / \mathbf{l}) \\
\text { Mean }\end{array}$ & \multicolumn{2}{c}{$\begin{array}{c}\mathbf{N H}_{\mathbf{4}}{ }^{+}(\mathbf{m g} / \mathbf{l}) \\
\text { Mean }\end{array}$} & \multicolumn{2}{c}{$\begin{array}{c}\mathbf{N O}_{\mathbf{2}}^{-}(\mathbf{m g} / \mathbf{l}) \\
\text { Mean }\end{array}$} & \multicolumn{2}{c}{$\begin{array}{c}\mathbf{N O}_{3}^{-}(\mathbf{m g} / \mathbf{l}) \\
\text { Mean }\end{array}$} & \multicolumn{2}{c}{$\begin{array}{c}\text { BOD(mg/l) } \\
\text { Mean }\end{array}$} \\
\cline { 2 - 11 } & $\mathbf{T 1}$ & $\mathbf{T 2}$ & $\mathbf{T 1}$ & $\mathbf{T 2}$ & $\mathbf{T 1}$ & $\mathbf{T 2}$ & $\mathbf{T 1}$ & $\mathbf{T 2}$ & $\mathbf{T 1}$ & $\mathbf{T 2}$ \\
\hline May & 0.1 & 0.18 & 0.99 & 1.1 & 2.75 & 1.95 & 2.95 & 2.31 & 4.79 & 4.55 \\
June & 0.04 & 0.14 & 0.77 & 1.07 & 1.36 & 1.56 & 4.01 & 3.21 & 4.29 & 4.31 \\
July & 0.05 & 0.07 & 0.7 & 0.7 & 1.3 & 1.43 & 4.12 & 3.78 & 4.35 & 4.18 \\
August & 0.1 & 0.12 & 0.98 & 0.98 & 2.79 & 2 & 2.71 & 2.31 & 5.23 & 4.23 \\
Average & 0.07 & 0.13 & 0.86 & 0.96 & 2.05 & 1.74 & 3.45 & 2.9 & 4.67 & 4.32 \\
\hline
\end{tabular}

\section{Survival and Growth Rate:}

Survival and Growth Rate data of RMS for mini farm were depicted for both species $S$. aurata and D. labrax under studying (Table 6), it could be notice that the survival rate was $96 \%$ and $91 \%$ for S. aurata and $76.7 \%$ and $81.6 \%$ for D. labrax in $\mathrm{T} 1$ and T2 respectively. The weight gain WG gm/fish were $66.5 \mathrm{gm} /$ fish and 72.34 $\mathrm{gm} /$ fish for $S$. aurata and $43 \mathrm{gm} /$ fish and $47.5 \mathrm{gm} /$ fish for D. labrax in T1 and T2 respectively.

Concerning the average daily gain (ADG) gm/fish/day, the results revealed that it ranged between 0.350 and 0.381 for $S$. aurata and between 0.358 and 0.396 for $D$. labrax in T1 and T2 respectively. While, the specific growth rate SGR the results explained that it ranged between 4.62 and 4.67 for $S$. aurata and 3.81 and 3.91 for $D$. labrax in $\mathrm{T} 1$ and $\mathrm{T} 2$ respectively (Table 6). 
Table 6: Survival Growth Parameters of S. Aurata and D. Labrax Reared in RMS System Mini Fish Farm

\begin{tabular}{|c|c|c|c|c|}
\hline \multirow[b]{2}{*}{ Parameters } & \multicolumn{2}{|c|}{ Gilthead sea-bream } & \multicolumn{2}{|c|}{ Sea bass } \\
\hline & $\begin{array}{c}\left(100 \mathrm{fish} / \mathrm{m}^{3}\right) \\
\mathrm{T1}\end{array}$ & $\begin{array}{c}\left(100 \mathrm{fish} / \mathrm{m}^{3}\right) \\
\mathrm{T} 2 \\
\end{array}$ & $\begin{array}{c}\left(100 \mathrm{fish} / \mathrm{m}^{3}\right) \\
\text { T1 }\end{array}$ & $\begin{array}{c}\left(100 \mathrm{fish} / \mathrm{m}^{3}\right) \\
\mathrm{T} 2\end{array}$ \\
\hline Survival (\%) & 96 & 91 & 76.7 & 81.6 \\
\hline Initial weight $\left(\mathrm{g}\right.$ fish $\left.^{-1}\right)$ & 36.66 & 36.66 & 2.6 & 2.6 \\
\hline Initial length ( $\left.\mathrm{g} \mathrm{fish}^{-1}\right)$ & 14.22 & 14.22 & 8.5 & 8.5 \\
\hline Final weight $\left(\mathrm{g} \mathrm{fish}^{-1}\right)$ & 103.17 & 109 & 45.6 & 50.1 \\
\hline Final length $\left(\mathrm{g} \mathrm{fish}^{-1}\right)$ & 19.22 & 21.11 & 12.2 & 13.5 \\
\hline $\mathrm{WG}\left(\mathrm{g}\right.$ fish $\left.^{-1}\right)$ & 66.51 & 72.34 & 43 & 47.5 \\
\hline $\begin{array}{l}\text { Average daily } \\
\text { gain(ADG)g/fish/day }\end{array}$ & 0.350 & 0.381 & 0.358 & 0.396 \\
\hline Percent gain in weight $(\%)$ & 176.28 & 197.33 & 1653.85 & 1826.92 \\
\hline $\operatorname{SGR}\left(\%\right.$ day $^{-1}$ fish $\left.^{-1}\right)$ & 4.62 & 4,67 & 3.81 & 3.91 \\
\hline condition Factor (K) & 1.45 & 1.14 & 2.51 & 2.04 \\
\hline $\mathrm{FI}\left(\mathrm{g} \mathrm{fish}^{-1}\right)$ & 150 & 150 & 100 & 100 \\
\hline FCR food conversion rate & 2.26 & 2.07 & 2.33 & 2.11 \\
\hline Protein efficiency ratio(PER) & 1.0 & 1.1 & 1.2 & 1.6 \\
\hline
\end{tabular}

The food conversion rate FCR revealed that it ranged between 2.26 and 2.07 for $S$. aurata, while D. labrax between 2.33 and 2.11 respectively. Moreover, the protein efficiency ratio PER were 1.0, 1.1, 1.2 and 1.6 for $S$. aurata and D. labrax in $\mathrm{T} 1$ and $\mathrm{T} 2$ as shown in Table 6 . Therefore, the results are in acceptable range and agreement with (Hamza, 1998).

Moreover the results revealed that the percent gain in weight; condition factors $\mathrm{K}$, food conversion ratio (FCR) and protein efficiency ratio (PER) were less for $S$. aurata than D. labrax (Table 6).

These results may be referring to the smallest initial length and weight of $D$. labrax (larval stage). Also, the results of $\mathrm{T} 2$ for both species were always higher than that $\mathrm{T} 1$.

Growth Studies for the length-weight relationship of combined sex of S. aurata is represented in (Fig. 2).

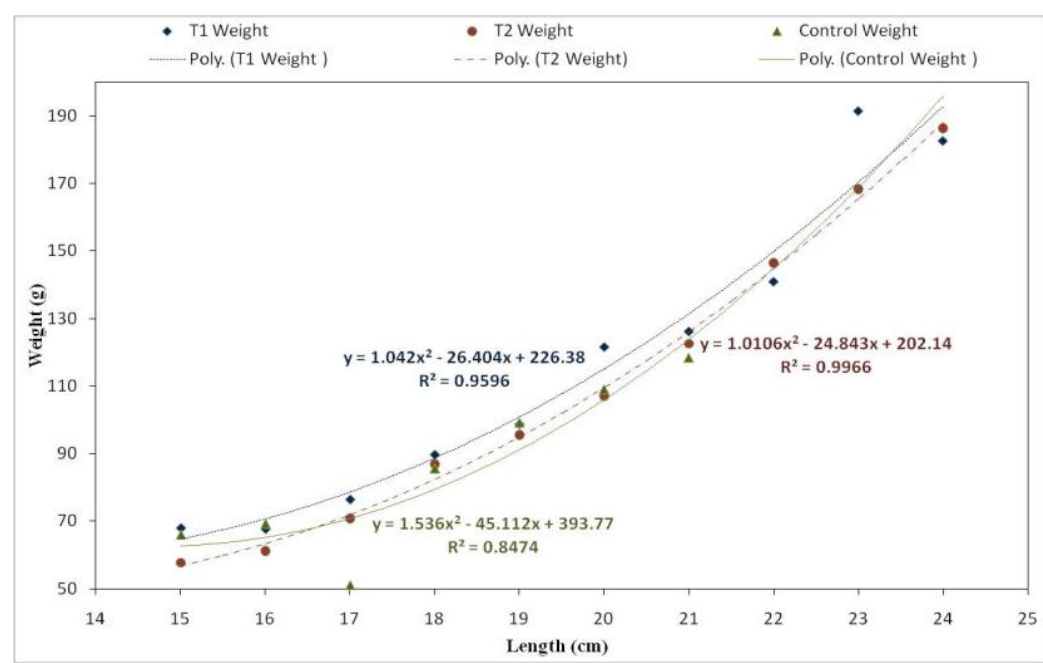

Fig. 2: Length-Weight Relation of Sea Bream Reared in Rearing Tanks (T1, T2) and Control

The curvi-linear relationship shows the calculated weight at each length interval for T1 and T2. The parabolic relationship between the calculated weight and length indicated that the higher length the increase in weight as show Fig.(2). 
These results indicated the significant success of rearing fingerlings $S$. aurata and larval stage of D. labrax in RMS for mini farm was achieved in water management by improving the efficiency of biological filter and the separation of organic matter through the use of RMS for mini farm.

Moreover the success rearing of fingerlings $S$. aurata represented by high survival percentage and growth parameter refer to the optimization of RAS have been concerning temperature, salinity effects, DO requirement, light intensity referred levels and photoperiod.

From the previous results it can be conclude that the success rearing of $S$. aurata and D. labrax in the RMS and could generate profit in mariculture fish species. Also, the success rearing is referring to the bio-filter which manages the environmental water-quality to acceptable limit.

\section{REFERENCES}

Ahmed, O. O.; Akinwole, A.O and Ajani E. K. (2015). Study of Interrelationship Among Water Quality Parameters in Earthen Pond and Concrete Tank. PeerJ PrePrints 3:e845v1.

Association of Official Analytical Chemists (AOAC) (1995). International Official Methods of Analysis, $16^{\text {th }}$ edition, Arlington, Virginia, USA.

Attia, M. A.; Helal, A. M. and Mustafa, M. M. (2017). Decision support system for Management Fish farms. Life Sci J;14(7). ISSN: 1097-8135 (Print) / ISSN: 2372-613X (Online).

Bhatnagar, A.; Jana, S.N.; Garg, S.K.; Patra, B.C.; Singh, G. and Barman, U.K. (2004). Water Quality Management in Aquaculture, In: Course Manual of Summerschool on Development of Sustainable Aquaculture Technology in Fresh and Saline Waters, Hisar (India): CCS Haryana Agricultural.

Bhatnagar, A. and Devi, P. (2013). Water quality guidelines for the management of pond fish culture. Int J Environ Sci, 3(6).

Ekubo, A. A. and Abowei, J. F. N. (2011). Review of Some Water Quality Management Principles in Culture Fisheries. Res J Appl Sci Engineering Technol, 3(2).

Fahmy, M. A. (2001). Preliminary study on the hydrochemistry of the Egyptian coastal water of Aqaba Gulf, as unique ecosystem during year 2000', Bulltein Institue of Oceanography and Fisheries. Egypt, 27: 95-112.

FAO (2013). A Global Assessment of Offshore Mariculture Potential From a Spatial Perspective.

FAO (2015). Guide to Recirculation Aquaculture.

Hamza, K. A. (1998). Brackish Water Cage Culture of Sea Bream Sparus Aurata and Sea Bass Dicentrachus Labrax in Mex Fish Farm. Bull. Fac., Zagazig Univ., 20(1).

Iliyasu, A.; Mohamed, A. Z.; Ismail, M. M.; Amin, M. A. and Mazuki, H. (2016). Technical Efficiency of Cage Fish Farming in Peninsular Malaysia: A Stochastic Frontier Production Approach. Aquaculture Res, 47(1).

Jamabo, N.A. (2008). Ecology of Tympanotonus fuscatus (Linnaeus, 1758) in the Mangrove Swamps of the Upper Bonny River, Niger Delta, Nigeria. Ph.D. Thesis, Rivers State University of Science and Technology, Port Harcourt, Nigeria, pp 231. 
Le cren, E. D. (1951). The length-weight relationship and seasonal cycle in gonadweight and condition in the perch Percafluviatilis,Journal of Animal Ecology, 20(2): 201-219.

Ornamental Aquatic Trade Association (OATA) (2008). Water Quality Criteria. Version 2.0. England, UK: OATA.

Saloom M.E. and Duncan R.S. (2005). Low dissolved oxygen levels reduce antipredator behaviours of the fresh water Clam Corbicula fluminea. Fresh Water Biol, 50.

Santhosh, B. and Singh, N.P. (2007). Guidelines for Water Quality Management for Fish Culture in Tripura, ICAR Research Complex for NEH Region, Tripura Center; Publication No.29.

Savary-Auzeloux, I.; Mosoni, L.; Rémond, D.; Dardevet, D.; Boirie, Y.; Walrand, S. and Guillet, C. (2014). Protein Digestion, Absorption and Metabolism. Research Gate, Available from: https://www.researchgate.net/profile/ Dominique_Dardevet/publication/260626399_Protein_Digestion_Absorption_ and_Metabolism/links/00463531db798c5a9d000000.

Sipaúba Tavares, L. H. and Magalhães Santeiro, R. (2013). Fish farm and water quality management. Acta Scientiarum Biol Sci, 35 (1): 21-27.

Stone, N. M. and Thomforde H. K. (2004). Understanding Your Fish Pond Water Analysis Report. Cooperative Extension Program, University of Arkansas at Pine Bluff. 